Valentyna Mazurenko, $\mathrm{PhD}$, Professor, Professor of the International Business Department of the Institute of International Relations of Taras Shevchenko National University of Kyiv. (Kyiv, Ukraine)

Alina Vorobiova, Postgraduate student of the Department of International Finance, Faculty of International Economics and Management, Kyiv National Economic University named after Vadym Hetman (Kyiv, Ukraine)

\title{
NEW TRENDS IN ISLAMIC FINANCE DURING THE TRANSFORMATION OF THE WORLD ECONOMY
}

Abstract. The article highlights the essential characteristics of the Islamic financial system, its main components and dimensions; identifies the latest trends in the development of Islamic finance in the transformation of the world economy. The peculiarities of the transformation of Islamic finances themselves are revealed. Changes in the distribution of participants in the financial market after Brexit and the impact of the effects of the COVID-19 pandemic on the viability of Islamic finance are outlined. The prospects of their implementation in Great Britain and "strategic centers - colonies" are proved. The preconditions for the formation of an alternative approach to solving the problems of the financial sphere in modern conditions are determined.

Keywords: Islamic finance, transformation, financial system, world economy, financial centers

Introduction. Despite its relatively small size, the Islamic banking sector has grown tremendously in recent years. According to the IMF, Islamic lenders have outperformed conventional banks over the past decade, and there are still many ways to maintain this growing trend. In almost 20 years, the capital of Islamic banks has increased from $\$ 200$ billion. up to $\$ 2.2$ trillion According to a report by Thomson Reuters, Sharia-compliant financial assets will reach $\$ 3.8$ trillion by 2023 , with an average annual growth rate of 10 percent.

Islamic banks have achieved this by using new opportunities, such as the digitalization of the banking sector. According to IFN Fintech, there are more than 100 Islamic Fintech companies in the world today. By increasing robotic consultants and creating alternative asset markets, these companies can significantly increase their financial presence in North America 
and the Middle East, where there is still a relatively large percentage of the population that is still not provided with banks and related services ${ }^{1}$.

The topic of the study is also important in that Islamic banking has proved to be more stable and has proven its ability to operate almost smoothly during the global financial crisis (Batorshyna, Igonina, Vagizova, Sabirzyanov 2016, p.265-269). Moreover, Islamic funding is actively developing not only in Muslim but also in non-Muslim countries, in particular in Great Britain, France and Switzerland.

Analysis of recent research and publications has been conducted. Issues of development of Islamic finance and Islamic banking are reflected in the works of foreign scholars (Mansur Khan, Ishaq Batti, H. Askari, Z. Iqbal, N. Krichen, A. Mirahor, Muhammad Umer Chapra, F. Sufyan, M. Noor, M Zulkibri, Mahmoud El-Gamal, Mohammed El Korchi) and domestic economists (O.M. Mozgovyi, O.V. Subochev, O.M. Yurkevich, E.M. Kiyan).

Essential characteristics of the Islamic financial system. The Islamic financial and banking system is a system whose principles of functioning and activity are based on Islamic law, ie on the laws of "Sharia". All banking operations of Islamic banks must take place on the basis of "Sharia", whether deposits, financing, etc. For a better understanding of the Islamic banking system, consideration should begin with delving into the historical genesis of Islamic economic thought.

Unlike traditional banks, where profits are the sole purpose, Islamic banks are based on two key factors - religion and profit. Profit maximization is the main goal of Islamic institutions, but at the same time this desire must be in harmony with the religious aspect. The method of profit of Islamic banks in connection with the ban on loan, or bank interest (the so-called usurious interest) - "ryba" - is based on investment.

All Islamic banking products (services), according to the principle of formation, are divided into three types:

1. Banking product based on partnership (or "profit / profit sharing"): mudaraba and musharaka;

2. Banking product based on participation in agreements (or "debt under the agreement"): Murabaha, Ijara (leasing), Salam, Istinsna, Istijrar, Kardulhasan, Wadiya

\footnotetext{
${ }^{1}$ Toward A. Global Islamic Finance Standard. 2018. URL : https://www.gfmag.com/magazine/march2018/toward-global-islamicfinance-standard (date of the application: 16.11.2020).
} 
3. Banking product based on the payment of commissions (tariffs) of the bank (or "commission" products): Vakala (letter of credit).

Islamic banks are the largest investors, using the assets of depositors, Islamic banks significantly increase them. Thus, for its purposes, the established Islamic bank must unite and find a balance between the religion of monotheism, moral aspects and business, which pays great attention to profit. If there is only one element in the value system of an Islamic bank - the moral side - it is likely that the bank will face losses and will be forced to cease its activities. If this happens, not only investors will lose, but according to Sharia philosophy all Muslims will have a hard time (World Bank and Islamic Development Bank Group. 2016, p. 218).

The main characteristics that distinguish the activities of Islamic banks from traditional ones are presented in Table 1.

Table 1.

The main differences between Islamic and traditional banks

\begin{tabular}{|c|c|c|}
\hline $\begin{array}{c}\text { Charanteed payments on } \\
\text { demand deposits }\end{array}$ & Islamic banks & Traditional banks \\
\hline Interest rate on deposits & $\begin{array}{c}\text { Not defined, not guaranteed } \\
\text { for investment deposits }\end{array}$ & Defined, guaranteed \\
\hline The purpose of the loan & $\begin{array}{c}\text { The loan is issued only for } \\
\text { investment purposes } \\
\text { determining the interest rate } \\
\text { on deposits }\end{array}$ & $\begin{array}{c}\text { Determined by the } \\
\text { profitability of the bank } \\
\text { by investment }\end{array}$ \\
\hline $\begin{array}{c}\text { Participation of depositors in } \\
\text { the profits and losses of the } \\
\text { bank }\end{array}$ & $\begin{array}{c}\text { Return on investment does } \\
\text { not depend on the } \\
\text { profitability of the bank }\end{array}$ \\
\hline Loan condition & $\begin{array}{c}\text { The issuance of the loan is } \\
\text { determined by the assessment } \\
\text { financial condition of the } \\
\text { borrower }\end{array}$ & $\begin{array}{c}\text { Mandatory condition of the } \\
\text { conclusion } \\
\text { agreement with the bank is } \\
\text { the existence } \\
\text { investment asset }\end{array}$ \\
\hline
\end{tabular}

Source: developed by the author on the basis ${ }^{2}$

Features of transformation in the post-crisis period. The results of the IMF study showed that during the crisis and in the post-crisis period, the growth of assets of Islamic

\footnotetext{
${ }^{2}$ Petrenko F. A. Islamskie banki kto oni? http://www.knukimedu.kiev.ua/?id=649\&amp;view=article (date of the application: 14.11.2020).
} 
banks exceeded that of traditional banks more than twice. Contrary to expectations, lower credit rates, small investment portfolios, and adherence to Sharia principles, which usually negatively affect competitiveness, have had a positive effect on the Islamic banking system.

However, the average assets of Islamic banks are still smaller than traditional ones. The economic policies of Islamic banks have allowed them to contain the negative effects of the coronary crisis.

Islamic banks supported lending twice as much as conventional banks. This suggests that they have made a greater contribution to maintaining macroeconomic and financial stability through more affordable lending. Islamic banks are closer to the real economy than conventional banks, as they do not offer conditional or virtual products. It is likely that the market share of Islamic banks will continue to grow.

However, the crisis has also revealed the shortcomings of Islamic banks. Priority areas for their development have been identified: strengthening financial regulation and supervision. The development of Islamic banks is constrained by a number of factors related to the specifics of their activities:

- differences in the application of standards of supervision and accounting;

- the presence of a risk of Sharia non-compliance;

- difficulties in liquidity management;

- shortage of risk hedging instruments;

- lack of qualified personnel.

Despite the existing barriers to the development and proliferation of Islamic banks, the industry is one of the fastest growing in the global financial services industry.

The entry of Islamic financing into Western markets indicates that it is taken seriously by regulators and financial institutions (Sundararajan, Errico 2018. p.15-22). And the crisis has proven that Islamic banking products are a competitive alternative to traditional ones.

According to experts, the main trends in the development of Islamic banks in the coming years will be:

- strengthening positions in the market segments of middle- and low-income social groups, in small and medium-sized businesses, and in the financial markets of developing countries with a large share of the Muslim population;

- gradual transition from quantitative growth of Islamic financial products to their simplification and standardization;

- growing importance of financial innovations and risk hedging instruments. 
For the further geographical expansion of Islamic banking, it is first necessary to create the appropriate infrastructure, which is most developed in most GCC countries, Iraq, Iran and Malaysia (Standard \& Poor's 2019). The existing financial centers are located in Bahrain, Malaysia, the UAE and the United Kingdom.

According to Ernst \& Young, there will be significant economic growth in the Middle East and North Africa in the near future. Islamic banking assets in the region are projected to reach $\$ 990$ billion. by 2021 , Oman announced its intention to join the development of Islamic banks and meet regional demand for Sharia-compliant products in order to reduce the outflow of investment from the country.

Sovereign Islamic bonds (sukuk) are planned to be issued in Egypt. Tunisia and Libya are considering increasing the role of Islamic banking in their economies. Among Western countries, the United Kingdom plays an active role in the development of Islamic banks, which according to some estimates has 22 banks that provide Sharia-compliant services (5 banks - fully Islamic).

Britain is followed by the United States in the number of Islamic banks. Islamic banks are also present in Australia, Switzerland, France, Canada, Germany, Luxembourg, Ireland, Kazakhstan and the Cayman Islands. Islamic banks are actively opening in countries with the most developed banking sector and high investment potential ${ }^{3}$.

The following facts testify to the prospects for the development of this industry. First, it is the Muslims who control the largest deposits of hydrocarbons, which will soon remain the main source of energy in the world. Significant revenues from the sale of these raw materials will long form the basis for the development of this industry.

Second, the escalating conflict between Islamic culture and Western culture is stimulating the transfer of Muslim funds from the traditional to the Islamic banking system.

Third, the conditional freeness of Islamic banks' liabilities pushes traditional bankers, armed with financial engineering experience, to compete for these liabilities. Competition in the industry stimulates the improvement of banking methods based on religious principles.

Fourth, many large multinational corporations are becoming customers of the Islamic banking system. They are interested in lower fees for the use of borrowed funds, and for Islamic banks, the reliability of the return of borrowed funds is attractive.

\footnotetext{
${ }^{3}$ Maierbrugger A. Islamic finance bodies to assess coronavirus damage on industry, pledge support [Electronic resource] / Arno Maierbrugger // Gulf Times, Bangkok. -2020. - Access mode: https://m.gulftimes.com/story/658591/Islamic-finance-bodies-to-assess-coronavirus-damage-on-industry-pledgesupport. (date of the application: 14.11.2020).
} 
Fifth, the development of a Sharia-based capital market and the introduction of a single Islamic currency will provide additional impetus to the development of the banking sector ${ }^{4}$.

At the same time, there is an opinion that the banking industry, based on the religion of Islam, cannot go beyond a certain niche. Its development is limited precisely by the religious consciousness of the Muslim, as the refusal of loan interest, speculation, repayment of borrowed funds, their intended use and profit sharing is another act of faith for the orthodox.

Given these views, it should be noted that the development potential of the Islamic banking system deserves attention not only in technical and quantitative terms, but also as a new philosophy of the global community, absolutely involves the introduction of ethical constraints on human activities (whether timber or financial services).

As the coronavirus continues to spread around the world and cause a series of economic shocks along the way, several umbrella Islamic financial organizations have begun to assess the potential damage the virus is doing to Islamic finance, banking and the halal industry as a whole.

The Islamic Development Bank, a multilateral financial development institution that has supported the Islamic finance industry in its 57 member states, said in a statement that it was deeply concerned about deaths, socio-economic shocks and the burden on the health systems of the countries affected. pandemic. The Bank expressed solidarity with its member countries and provided support to counter the threat posed by COVID-19 to its members in the short, medium and long term.

To support member countries in the rapid spread of coronavirus, the Islamic Development Bank (IDB) Group has set up a special Strategic Preparedness and Response Fund worth $\$ 730$ million. The United States to mitigate the negative impact of the pandemic on the health and socioeconomic situation that continues to spread around the world. The fund provided funding to both the public and private sectors to minimize the spread and impact of the pandemic in IDB member countries and increase their resilience.

The IDB used all available funding instruments to accelerate the allocation of funds to support its member countries. Funding was provided for emergency preparedness and response measures, as well as for controlling the spread of COVID-19, minimizing the socio-economic impact of the pandemic, especially on the poor, and increasing the resilience of

\footnotetext{
${ }^{4}$ United Bank Ltd., Glossary of Islamic Banking Terminology, https://www.ubl.com.pk/ameen/pdf/ Glossary_Islamic_Banking.pdf (date of the application: 12.11.2020).
} 
member countries to disease outbreaks. and pandemics. The IDB also supported strengthening health care systems, funding national epidemic preparedness and response plans, public awareness and education, disease surveillance, data collection and analysis, sustainable provision of basic social services, social protection networks, and support. private sector ${ }^{5}$.

The IDB team will also invest in research and development and provide technical assistance to prevent and contain the pandemic. In addition, the Bank used its feedback program to share experiences, advanced technologies, technical knowledge in the field of response and management from other member countries.

Measures imposed by governments to prevent the spread of the pandemic have led to the partial or complete shutdown of enterprises. Against this background, new opportunities have appeared in the companies of the Fintechnology sector. Thus, according to a report by Tech Nation and Dealroom, Fintech has shown resilience during the coronary crisis, and in 2020, London's technology companies accounted for 39\% of all venture capital.

Wahed Invest chief strategist Mehdi Bensliman believes that the current economic crisis, which is taking place against the backdrop of the coronavirus pandemic, has become an alarming call for the world economy. Therefore, market participants should look closely at the methods of making money. At the same time, companies operating in the Islamic finance sector can emerge from the crisis with good results. "This crisis is a call for us to change the way we work in the context of investment. They need to become more sustainable, with an emphasis on environmental aspects, "he said. After the crisis, Mehdi Bensliman said, companies in the Islamic finance sector will have "good positions in terms of investment and financing". As a result, the current crisis may trigger the next stage in the development of Islamic financial institutions. As for Kazakhstan, the development of Islamic finance requires the development of legislation and the promotion of financial literacy among the population in order to succeed in the development of Islamic finance in its market. The Astana International Financial Center, which supports the emergence of new financial instruments in the country and the region as a whole, can help ${ }^{6}$.

\footnotetext{
${ }^{5}$ Gross A. Iran to grant credit to $23 \mathrm{~m}$ families to limit economic impact of virus [Electronic resource] / Anna Gross // Financial Times. - 2020.11.11.2020)..

${ }^{6}$ Astana Finance Days: experts on the challenges and opportunities of the Islamic finance and fintech industry in the post-pandemic era; https://primeminister.kz/ru/news/reviews/astana-finance-days-eksperty-o-vyzovah-ivozmozhnostyah-industrii-islamskih-finansov-i-finteh-v-epohu-post-pandemii-165313 (date of the application: 16.11.2020).
} 
Great Britain and Islamic finance. Great Britain is the main Western center of Islamic Finance. Institutions in London and other cities have been providing Islamic Finance and related services for almost 40 years.

The UK ranks above other important financial centers in terms of the supply of Islamic Finance products. The latest report from the Islamic Corporation for the Development of the Private Sector gave the UK an index of 16.2, which is higher than the world average of 10.3, highlighting the highest level among countries with a predominantly non-Muslim population.

Currently, 5 fully Sharia-compliant commercial banks are licensed, which is the largest number among Western countries. The fixed assets of these banks amounted to 3.6 billion US dollars by the end of 2017.

There are also several traditional banks that provide services under Islamic finance. In total, more than 20 banks in the UK provide these services. These figures are significantly higher than the number of institutions in any European country or offshore center, almost twice the number of such banks in the United States. The total amount of fixed assets of banks providing services and products of Islamic Finance reached 4.5 billion US dollars by the end of 2017.

In recent years, the Islamic finance retail market has begun to develop with the introduction of Sharia-compliant products, such as registered savings accounts, home acquisition plans, pension schemes and new business financing.

The government is also developing programs to fund training in Islamic Finance. There are already more than 100,000 customers of Islamic Finance retail products in the UK. The London Stock Exchange (LSE) is the main place of issue of Islamic Securities (Sukuk). To date, 57 such securities have been issued in the amount of $\$ 51$ billion. USA. Net assets of Islamic funds in the UK reach $\$ 600$ million. Also on the London Stock Exchange (LSE) are listed in accordance with Sharia law 4 Exchange Investment Funds and 2 Exchange Investment Products. Banking, Islamic securities (Sukuk), exchange-traded investment products, complemented by leading professional services, provide support for the implementation of Islamic Finance transactions and transactions. The services are provided by financial intermediaries who manage assets, insurance service providers and more than 30 international law, auditing and consulting firms.

As the penetration of Islamic finance grows, so does the demand for the relevant skills. Educational institutions in the UK are at the forefront of providing academic and professional qualifications in this field. The United Kingdom is a global center of Islamic Finance education and training, with 4 professional institutions and more than 70 universities and 
business schools providing courses and diplomas in the Islamic Finance sector. Islamic Finance plays a significant role in the UK's infrastructure development. This includes funding for the refurbishment of London's Chardin and Battersea Power Station, London Gateway, the Olympic Village and the redevelopment of Chelsea Barracks. More than 6,500 homes in the North West and Central County are funded with a \$1 billion investment, fully compliant with Sharia Bank Gatehouse standards. Existing trends point to the growing role of Islamic finance in financing infrastructure projects.

An important feature of the development of the United Kingdom as a center of Islamic finance is a wide range of government initiatives taken over the past decade, have created a fiscal and legal basis for expanding the market for Islamic Finance products.

Islamic finance in the UK operates in accordance with legislation that applies to all other sectors - so this means "common rules of the game" for both traditional and Islamic finance products ${ }^{7}$.

Conclusion. The global coronary crisis has given Islamic banks the opportunity to demonstrate their resilience, but at the same time has revealed some important issues that need to be addressed so that they can continue to grow at a steady pace.

1) Lack of strong liquidity risk management infrastructure. Relying on retail deposits to a greater extent than traditional banks, Islamic banks, accordingly, have more stable sources of funds, but they face fundamental difficulties when it comes to liquidity management, including:

- shallow money market due to the small number of participants;

- lack of instruments that could be used as collateral for borrowing or discounting (selling) through the central bank's re-accounting mechanism.

2) Some Islamic banks solve these problems through excessive liquidity of the balance sheet (ie, maintaining a significant amount of quasi-monetary assets that yield lower incomes than loans and many types of securities), thus sacrificing profitability. Thus, Islamic financial institutions retain $40 \%$ more liquidity than their traditional counterparts. However, this approach to liquidity has reduced risks during the crisis, but is not the optimal solution under stable conditions.

\footnotetext{
${ }^{7}$ Development of Islamic Funding Principles in the UK [Електронний ресурс] // gov.uk. - 2020. - Режим доступу до ресурсу: https://assets.publishing.service.gov.uk/government/uploads/system/uploads/ attachment_data/file/503492/2015047_Is_Fin_A5_AW_RUS_WEB.pdf .
} 
To the extent that Islamic banks try to behave like traditional banks in developing their financial products, they expose themselves to similar credit risk, liquidity risk and solvency, which lead to similar systemic instability that occurs in the traditional banking sector. The desire to resemble traditional banks is not a will, but the result of current activities and the regulatory framework, which does not provide all the necessary support and infrastructure of institutions that are necessary for a well-functioning Islamic banking sector.

\section{References:}

1. Astana Finance Days: experts on the challenges and opportunities of the Islamic finance and fintech industry in the post-pandemic era; https://primeminister.kz/ru/news/reviews/astanafinance-days-eksperty-o-vyzovah-i-vozmozhnostyah-industrii-islamskih-finansov-i-finteh-v-epohupost-pandemii-165313.

2. Batorshyna A., Igonina A., Vagizova V., Sabirzyanov A. Liquidity management in Islamic banking industry. Social Sciences and Interdisciplinary Behavior: CRC Press, 2016. P. 265-269

3. Development of Islamic Funding Principles in the UK // gov.uk. -2020. https://assets.publishing.service.gov.uk/government/uploads/system/uploads/attachment_data/file/503 492/2015047_Is_Fin_A5_AW_RUS_WEB.pdf.

4. Gross A. Iran to grant credit to $23 \mathrm{~m}$ families to limit economic impact of virus [Electronic resource] / Anna Gross // Financial Times. - 2020. - Access mode: https://www.ft.com/content/ db36991b-572c-3f1a-ae73-25078b512499.

5. Maierbrugger A. Islamic finance bodies to assess coronavirus damage on industry, pledge support [Electronic resource] / Arno Maierbrugger // Gulf Times, Bangkok. 2020. - Access mode: https://m.gulf-times.com/story/658591/Islamic-finance-bodies-to-assess-coronavirus-damage-onindustry-pledge-support.

6. Petrenko F. A. Islamskie banki kto oni? http://www.knukimedu.kiev.ua/ ?id=649\&amp; view=article.

7. Standard \& Poor's, «Islamic Finance Outlook 2018». The National Bureau of Asian Research. Islamic Finance: Global Trends and Challenges. 2019. No 4. V. 18.

8. Sundararajan V., Errico L. Islamic Financial Institutions and Products in the Global Financial System: Key Issues in Risk Management and Challenges Ahead, IMF Working Paper No. 02/192, November 1, 2018. P.15-22 https://doi.org/10.5089/9781451859775.001

9. Toward A. Global Islamic Finance Standard. 2018. URL : https://www.gfmag.com/ magazine/march-2018/toward-global-islamicfinance-standard 
10. United Bank Ltd., Glossary of Islamic Banking Terminology, https://www.ubl.com.pk/ ameen/pdf/Glossary_Islamic_Banking.pdf.

11. World Bank and Islamic Development Bank Group. 2016. Global Report on Islamic Finance: Islamic Finance: A Catalyst for Shared Prosperity. Washington, DC: World Bank. 218 p. 